\title{
DESIGN OF LOW VOLUME ROAD IN DALLO MANNA, ETHIOPIA
}

\author{
Jemal Aliy Gobena ${ }^{1}$, Lollo Chande Lollo ${ }^{2}$ \\ ${ }^{1}$ Lecturer, Department of Civil Engineering, Wolaita Sodo University, SNNPRS, Ethiopia. \\ ${ }^{2}$ Lecturer, Department of Civil Engineering, Wolaita Sodo University, SNNPRS, Ethiopia.
}

\begin{abstract}
Transportation by the road is the most used mode of transport in Ethiopia, especially in rural areas. However large portion of the rural residents are still isolated from the rest of the country due to lack of adequate road access. Only 37\% of the sub districts (Kebele) are accessible by all season roads. Communities are often left isolated and without access, particularly during periods of rains. This excludes them from exposure to new ideas and influences. Most of rural population in Ethiopia still relies on pack animals as means of transportation and carrying goods to market places. Thus improving existing road infrastructures and construction of new roads will improve the living conditions of the citezens, especially the rural residents. Recently Ethiopia is renowened as one of the fastest growing nation in the worled. In order to sustain nation's economic growth and reduce citezens poverty the government needs to address Ethiopia's severe infrastructures constraints. Less road network is one of the challenges of of nation's economic growth. To overcome the challenge, Ethiopia is implementing the Universal Rural Road Access Program (URRAP). It's objective to free the rural residents from their access constraints and to connect all Kebele by allweather roads. Low volume roads typically carry less than 300 vehicles per day and may extend up to the regional and federal networks. The majority of the total road network of the country can be considered as low volume roads. Since 1993 such roads have been administered by Regional Roads Authorities and Weredas. This paper aims for design of 6km long rural road in Bale district connecting Nanniga Dhera village to main roads. This paper discus about surveying and leveling of proposed road, Traffic Data survey, Laboratory test of material of construction and designing of road based on Ethiopian Road Authority (ERA) manual.
\end{abstract}

Keywords: ERA, CBR, Survey, Pavement Design, Geometric Design $* * *$

\section{INTRODUCTION}

Roads are one of the modes of transportation which could give maximum services to one and all. Low volume roads typically carry less than 300 vehicles per day and may extend up to the regional and federal networks. The majority of the total road network of the country can be considered as low volume roads.

\section{ROAD NETWORK CLASSIFICATION.}

The function of classification of roads in Ethiopia is based on five classes:

\subsection{Trunk roads:}

These are roads that link Addis Ababa to centers of international importance and to international boundaries.

\subsection{Link roads:}

These are roads connecting centers of national and international importance such as principal towns and urban centers.

\subsection{Main access:}

Roads connecting centers of provisional importance are termed as main roads

\subsection{Collector roads:}

Roads connecting locally important centers to each other or to a more important center or to a higher class road are classified as collector roads.

\subsection{Feeder roads:}

These are roads connecting minor centers such as a market to each other parts of the network.

\section{DESIGN OF RURAL ROADS}

In Ethiopia, rural roads are unpaved with a gravel or earth wearing surface. An essential consideration in the design of gravel roads is to ensure all-weather access. This requirement places particular emphasis on the need for sufficient bearing capacity of the pavement structure and provision of drainage and sufficient earthworks in flood or problem soil areas (e.g. black cotton).

The performance of the gravel surface mainly depends on material quality, the location of the road, and the volume of traffic using the road. Gravel roads passing through populated areas in particular require materials that do not generate excessive dust in dry weather. Steep gradients place particular demands on gravel wearing course materials, which must not become slippery in wet weather or erode easily. Consideration should therefore be given to the type of gravel wearing course material to be used in particular locations such as towns or steep sections. Gravel 
loss rates of about $25-30 \mathrm{~mm}$ thickness a year per 100 vehicles per day is expected, depending on rainfall and materials properties (particularly plasticity).

\subsection{Pavement and Materials}

Depending on the CBR design of the subgrade, improved subgrade layers shall be constructed as required, on which the gravel wearing course is placed.

\subsection{Material Requirements}

Knowledge of past performance of locally occurring materials for gravel roads is essential. Material standards may be altered to take advantage of available gravel sources provided they have proved to give satisfactory performance under similar conditions.

\section{AREA UNDER STUDY}

The study area is located within latitude $6^{\circ} 52^{\prime}$ and $6^{\circ} 48^{\prime} \mathrm{N}$ and longitude $37^{\circ} 49^{\prime}$ and $37^{\circ} 42^{\prime} \mathrm{E}$. The rural road under study connects Nanniga Dhera village of Dallo Manna werada with ERA main road. The Nanniga Dhera village consists of about 30,000 people. The road is about $6 \mathrm{~km}$ long. The road starts from ERA main road to Nanniga dhera.

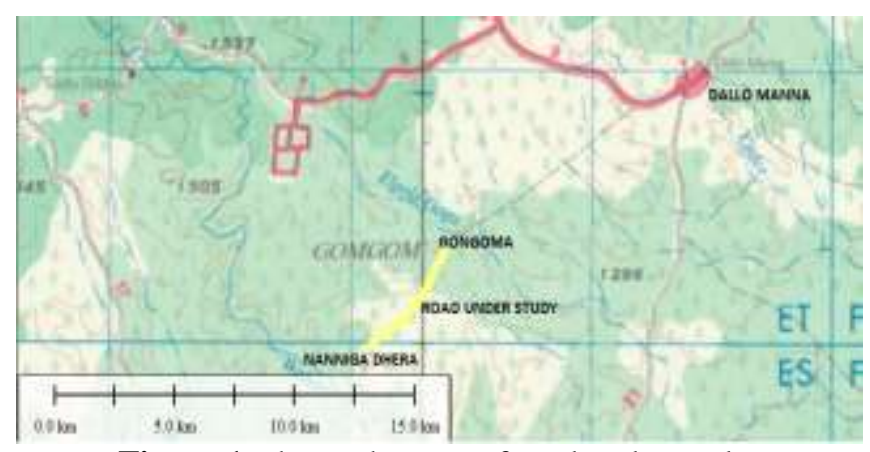

Figure 1: shows the map of road under study

\section{EXPERIMENTAL PROGRAM}

Handheld GPS (Global Positioning System) instruments have been used for the determination of preliminary lengths, chainages and locations during the field reconnaissance and field investigations. Equipment for the topographical survey works was temporarily imported and includes a combination of conventional land surveying instruments and selfregistering surveying equipment (total station) as follows:

a) Sokia set 2010 Total station

b) Prolink sokia 2010 computer software for transferring data, including connecting cable software.

c) Four prisms/reflectors, batteries, chargers, etc.;

d) Walk-talk radio with its charger

e) Levelling rods/hand bubble;Ancillaries like tripods, measuring tapes, range poles, etc.

Standard proctor test was used to determine the maximum dry density (MDD) and optimum moisture content (OMC) of the soil and CBR test was determined as per Ethiopia Road Authority (ERA) design manuals.

\section{RESULTS AND DISCUSSION}

\subsection{Survey}

The ground over which the road is proposed is plain. Hence small amount of cutting and filling is needed.

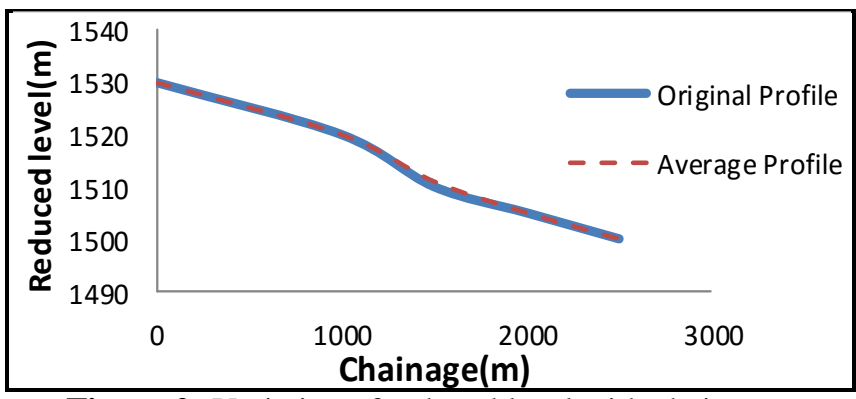

Figure 2: Variation of reduced level with chainages

\subsection{Compaction}

The optimum moisture content of the soil is $12 \%$ and maximum dry density of soil is $1.99 \mathrm{~g} / \mathrm{cm} 3$ by standard proctor test.

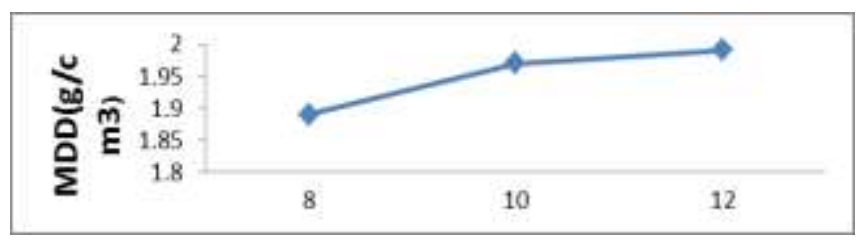

Figure 3: Graph obtained for calculation of O.M.C and M.D.D

\subsection{California bearing ratio test (CBR)}

Originally developed by the California Division of Highways, CBR test has been modified and has been the most common strength test conducted on soils to evaluate the strength of subgrade soil. It is dependent on the type of soil, its density and its moisture for highways and air field. Figure 5 shows CBR at 2.5 is $4.5 \%$ and CBR at 5.0 is $4.2 \%$. Since CBR at 2.5 is greater than CBR value at 5 so we have to design pavement keeping CBR $4.5 \%$. The test results have been corrected with flexible pavement thickness requirements.

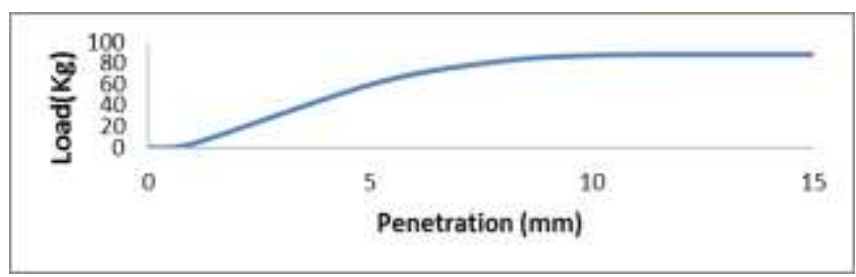

Figure 4: Variation of load with penetration for CBR test

6.4 Geometric Design as per ERA manual 2002

\subsubsection{Design Speed}


Table-1: Design speed recommended and taken

\begin{tabular}{|c|c|c|c|}
\hline \multirow{3}{*}{$\begin{array}{c}\text { Road } \\
\text { type }\end{array}$} & \multirow{2}{*}{\multicolumn{2}{|c|}{$\begin{array}{c}\text { Design speed } \\
\text { Plain terrain }\end{array}$}} & \multirow{3}{*}{$\begin{array}{l}\text { Taken } \\
\text { design } \\
\text { speed } \\
(\mathrm{kmph})\end{array}$} \\
\hline & & & \\
\hline & $\begin{array}{c}\text { Rolling design } \\
\text { speed }\end{array}$ & $\begin{array}{c}\text { Minimum } \\
\text { design speed }\end{array}$ & \\
\hline $\begin{array}{c}\text { Rural } \\
\text { road }\end{array}$ & 50 & 40 & 40 \\
\hline
\end{tabular}

\subsubsection{Road lane width}

Table-2: Road lane width recommended and taken

\begin{tabular}{|c|c|c|}
\hline Road type & $\begin{array}{c}\text { Road way } \\
\text { width(m) }\end{array}$ & $\begin{array}{c}\text { Taken Road way } \\
\text { width(m) }\end{array}$ \\
\hline Rural road & 6.00 & 6.00 \\
\hline
\end{tabular}

\subsubsection{Width of Road way in plain and rolling} terrain

Table-3: Width of Road way in plain

\begin{tabular}{|c|c|c|l|}
\hline \multirow{2}{*}{ Road type } & \multicolumn{2}{|c|}{ Road lane width } & \multirow{2}{*}{$\begin{array}{l}\text { Taken } \\
\text { lane width } \\
\text { (m) }\end{array}$} \\
\cline { 2 - 3 } & \multicolumn{2}{|c|}{ Plane and rolling terrain } & \\
\cline { 2 - 3 } & Open areas & Built up areas & \\
\hline Rural road & 6 & 8 & 6 \\
\hline
\end{tabular}

\subsubsection{Carriageway width}

Table-4: Recommended Carriageway width

\begin{tabular}{|c|c|c|}
\hline Road type & Carriage way width & $\begin{array}{c}\text { Taken carriage } \\
\text { way width }(\mathrm{m})\end{array}$ \\
\hline Rural road & 3.00 & 3.00 \\
\hline
\end{tabular}

\subsubsection{Camber (cross fall)}

Table-5: Recommended Camber and taken

\begin{tabular}{|c|c|c|c|}
\hline $\begin{array}{c}\text { S. } \\
\text { No. }\end{array}$ & Surface type & $\begin{array}{c}\text { Camber } \\
(\%)\end{array}$ & $\begin{array}{c}\text { Taken } \\
\text { camber }(\%)\end{array}$ \\
\hline 1 & Earth/Soil & 4 & 4 \\
\hline 2 & Black cotton soil & 4 & 4 \\
\hline
\end{tabular}

\subsubsection{Slope of cut}

Table-6: Slope of cut recommended and taken

\begin{tabular}{|c|c|c|}
\hline Type of soil & Slope & Taken slope \\
\hline Ordinary soil & $1: 3$ to $1: 4$ & $1: 3$ \\
\hline
\end{tabular}

\subsection{Pavement Design}

The pavement is one of the high cost items in any road construction project, whether new construction or upgrading or rehabilitation. Therefore, careful approach needs to be considered in order to achieve the aim of a well-designed pavement:

a) Riding comfort acceptable to road users; b) Economy (implementation / construction and life time / maintenance);

c) Limited surface deflection.

In general the requirements for pavement design of a road depend on planned design life, sub-grade soil type and traffic volume. The requirements place particular emphasis on the need for sufficient bearing capacity of the pavement problem soil areas (e.g. black cotton soil). ERA (Ethiopian Roads Authority) pavement Design Manual, Volume 1-2002 (Flexible pavement and materials design Manual, 1999, is used for determining the pavement components and thickness.

\section{CONCLUSION}

\subsection{Geometric Design}

The cross fall of carriage way and shoulders shall be $4 \%$ as per the ERA manual. The formation and carriageway width will be $3 \mathrm{~m}$.

\subsection{Pavement Design}

The annual average daily traffic of the road was less than 20. Therefore road thickness of $150 \mathrm{~mm}$ is recommended.

\section{REFERENCES}

[1] ERA (Ethiopian Roads Authority) pavement Design Manual, Volume 1 2002, Flexible pavement and materials design Manual, 1999.

[2] ERA (Ethiopian Roads Authority) pavement Design Manual, Volume 1-2002, geometric design Manual, 1999.

[3] Terzaghi, K, Pecil, R.B.\& Mesri, G.(1996). Soil Mechanics in Engineering Practice ThirdEdition, John Wiley, New York.

[4] Tomlinson, M.J.(2004). Site Investigation and Soil Mechanics. In foundation Design and Construction. fifth Edition, London: The Pitman Press, Bath.

[5] Bowles, J. E. (1996). Foundation Analysis and Design. McGraw Hill, New York. 